\section{Milk intake in pregnancy}

The article about milk intake during pregnancy and decreased birth weight ${ }^{1}$ has several flaws. It may also serve to perpetuate typical physician perceptions that bovine milk is necessary for human health.

The study found that pregnant women who restricted milk intake had babies that weighed $\mathrm{I} 20 \mathrm{~g}$ less on average than the babies of women who did not restrict milk intake. But the real questions are whether the lower birth weight had any negative clinical impact (acute or chronic) and whether the babies were underweight. Could there even have been benefits associated with delivering slightly smaller babies?

Both groups of women in the study had good protein intakes. Caloric intakes were almost equivalent. Does the small (Io g) difference in daily protein intakes between the 2 groups account for the difference in birth weights? How does one separate out the effect of vitamin D and calcium? Should we be measuring serum vitamin $\mathrm{D}$ levels to help quantify the differences in intake?

Note that there was no randomization in the study. Perhaps the women who restricted their milk intake also had restricted diets more generally. If the milk restrictors tended to eat smaller servings of food, then the diet surveys would have overestimated their protein and caloric intakes. I also wonder if natural bovine hormones in milk, or if hormonally active pesticides that bioaccumulate in milk, can increase birth weight.

People from my ethno-religious background are virtually all lactovegetarians and some are becoming vegans. I've heard dozens of stories about physicians telling family members and friends (both lacto-vegetarians and vegans) that they were hurting their unborn babies, their children and themselves and that they must consume meat. Physicians should be able to take an adequate history to determine whether any diet, vegan or otherwise, provides the micro- and macronutrients needed in pregnancy. A basic knowledge of vegetarian and vegan foods that provide protein and other nutrients is also necessary. For in- stance, physicians should note that vitamin $\mathrm{D}$ is added to milk and that soy milk now contains equivalent amounts of protein, calcium and vitamin $\mathrm{D}$.

\section{Tushar Mehta}

Substance Use Medical Service

St. Joseph's Health Centre

Toronto, Ont.

\section{REFERENCE}

I. Mannion CA, Gray-Donald K, Koski KG. Association of low intake of milk and vitamin D during pregnancy with decreased birth weight. CMAJ 2006;174(9):1273-7.

DOI:I0.I503/cmaj.I06oI23

\section{[The authors respond:]}

We appreciate Tushar Mehta's concerns. Our study ${ }^{1}$ was designed as a diet study and therefore we measured both supplement and food intakes of many nutrients, using the dietary reference intakes recently developed by Canadian and US experts. ${ }^{2}$ The media's "milk slant" on the article drew in readers and listeners, but this was a study about a dietary requirement for vitamin $\mathrm{D}$.

Initially we examined the quality of the diets of pregnant women who were in increasing numbers restricting their intake of fortified milk, which was one of the few good sources of vitamin D in the Canadian diet in I998. With the growing recognition that vitamin $\mathrm{D}$ deficiency is widespread in North Amer$\mathrm{ica}^{3,4}$ and that a dietary source of this vitamin is required in the winter months, more foods are now fortified with vitamin $\mathrm{D}$, including yogurt, rice and soy beverages, margarine, some infant formulas, meal replacements and readyto-eat cereals. Use of vitamin supplements is still encouraged, but the pregnant women in our study who needed supplements the most were not consuming them.

Mehta wonders whether the $120-9$ difference in birth weight that we observed is clinically relevant. At the recent Milk, Hormones, and Human Health Conference sponsored by Harvard University (www.milksymposium .org), preliminary data were presented from the Danish Birth Cohort Study (with IOI 042 recruits) showing a higher incidence of both small-for-gestational- age and large-for-gestational-age births with low and high milk intakes, respectively.

Milk is a complex biological fluid requiring further investigation, as more than I component could be responsible for its biological effects. In Canada, where pregnant women live at northern latitudes with limited sunlight exposure, vitamin $\mathrm{D}$ is one of these important nutrients. One of the consequences of inadequate vitamin $D$ consumption during pregnancy now appears to be reduced bone mineralization in childhood. ${ }^{5}$ Our study's conclusion that daily intake of vitamin $\mathrm{D}$ is required during pregnancy is an important public health message for Canadians.

\section{Kristine G. Koski}

Katherine Gray-Donald

School of Dietietics and Human

Nutrition

McGill University

Ste. Anne de Bellevue, Que.

Cynthia A. Mannion

Faculty of Nursing

University of Calgary

Calgary, Alta.

\section{REFERENCES}

I. Mannion CA, Gray-Donald K, Koski KG. Association of low intake of milk and vitamin $\mathrm{D}$ during pregnancy with decreased birth weight. CMA 2006;174(9):1273-7.

2. Institute of Medicine. Dietary DRI reference in takes: the essential guide to nutrient requirements. Washington (DC): The National Academies Press; 2006.

3. Schroth RJ, Lavelle CL, Moffatt ME. Review of vitamin D deficiency during pregnancy: Who is affected? Int J Circumpolar Health 2005;64(2):112-20.

4. Calvo MS, Whiting SJ. Prevalence of vitamin D insufficiency in Canada and the United States: importance to health status and efficacy of current food fortification and dietary supplement use. Nutr Rev 2003;6I(3):I07-I3.

5. Javaid MK, Crozier SR, Harvey NC, et al. Maternal vitamin D status during pregnancy and childhood bone mass at age 9 years: a longitudinal study. Lancet 2006;367:36-43.

DOI:I0.1503/cmaj.10700I7

\section{Time to reperfusion therapy}

In their article on delays to reperfusion therapy in the province of Quebec, Thao Huynh and associates concluded that for most patients the time to primary percutaneous coronary intervention exceeded current recommendations. ${ }^{1}$ This conclusion might be 
misleading because of some limitations of the study.

The authors did not exclude from their analysis patients for whom there was an explainable delay in the diagnosis of ST-segment elevation myocardial infarction. Some patients with suspected aortic dissection or pulmonary embolism may have undergone additional investigation prior to receiving reperfusion therapy. Also, it is not clear whether the authors excluded patients whose initial electrocardiogram was not diagnostic. A sizable number of patients with acute coronary syndromes may develop clear ST-segment elevation only after a follow-up electrocardiogram is done while they are under observation in the emergency department. Patients with a delayed diagnosis or a contraindication to thrombolytic therapy, or who need cardiopulmonary resuscitation, intubation or defibrillation, may be more likely to receive primary percutaneous coronary intervention. These patients are expected to have longer delays to reperfusion therapy. In particular, it appears that patients transferred from distant hospitals for primary percutaneous coronary intervention because of contraindications to thrombolytic therapy were included in the analysis.

Also, the authors do not clarify whether they included patients referred for rescue percutaneous coronary intervention. The data for these patients would obviously have increased the calculated delays to reperfusion therapy for transferred patients.

Door-to-balloon time is not always the best indicator of treatment delays. In our institution, we use door-toopen-artery time to measure treatment delays. As many as $29 \%$ of patients with ST-segment elevation will have thrombolysis in myocardial infarction (TIMI) scores of 2 or 3 for flow in the culprit vessel when the first coronary angiogram is done. ${ }^{2}$ In these patients, the operator may choose to take time to perform a ventriculogram and additional coronary views, administer additional medications or use a thrombus extraction catheter before performing coronary angioplasty. In these patients, door-to-open-artery time provides a better indication of delays to reperfusion therapy.

\section{Jean-Pierre Dery}

\section{Robert DeLarochellière}

Quebec Heart and Lung Institute

Hôpital Laval

Québec, Que.

\section{REFERENCES}

I. Huynh T, O'Loughlin J, Joseph L, et al; AMI-QUEBEC Study Investigators. Delays to reperfusion therapy in acute ST-segment elevation myocardial infarction: results from the AMI-QUEBEC Study. CMAJ 2006;175(12):1527-32.

2. Godicke J, Flather M, Noc M, et al. Early versus periprocedural administration of abciximab for primary angioplasty: a pooled analysis of 6 studies. Am Heart J 2005; 150(5):1015.

Competing interests: Dr. Dery holds a research grant from Eli Lilly.

DOI:I0.1503/cmaj.1060246

\section{[Four of the authors respond:]}

We thank Jean-Pierre Dery and Robert DeLarochellière for their comments. Although only $8 \%$ of patients who underwent primary percutaneous coronary intervention after interhospital transfer were treated within the recommended time in our study, $36 \%$ of those treated on site received therapy within the recommended time. ${ }^{1}$ Therefore, at least in this latter group, the time to primary percutaneous coronary intervention exceeded recommendations in many (but not most) patients.
To address Dery and DeLarochellière's concerns that inclusion of particular groups of patients may increase time delays to primary percutaneous coronary intervention, we undertook sensitivity analyses in which we excluded the following groups: patients who present with atypical symptoms (e.g., patients who may have aortic dissection and pulmonary embolism), patients with initial electrocardiograms that are nondiagnostic, patients with contraindications to fibrinolytic therapy and patients who required intubation and cardiopulmonary resuscitation for stabilization. The time to primary percutaneous coronary intervention remained prolonged even after exclusion of these patients (Table I).

Dery and DeLarochellière were also concerned that we may have included patients who underwent rescue percutaneous coronary intervention. As the objective of our study was to measure time delays to initial reperfusion therapy (i.e., primary percutaneous coronary intervention and fibrinolytic therapy), we did not include patients who underwent rescue percutaneous coronary intervention. Only patients who underwent primary percutaneous coronary intervention without prior administration of fibrinolytic therapy were retained for analysis.

Door-to-open-artery time is difficult to determine accurately, because the exact time when the artery opens is of-

Table 1: Sensitivity analyses exploring the effect on door-to-balloon time of excluding various groups of patients

\begin{tabular}{lcc}
\hline & \multicolumn{2}{c}{$\begin{array}{c}\text { Time from arrival at hospital } \\
\text { to primary PCI, min }\end{array}$} \\
\cline { 2 - 3 } Analysis & $\begin{array}{c}\text { On-site } \\
\text { primary PCl }\end{array}$ & $\begin{array}{c}\text { Primary PCl after } \\
\text { interhospital transfer }\end{array}$ \\
\hline $\begin{array}{l}\text { All patients included } \\
\text { Excluding } 9 \text { patients with atypical } \\
\text { symptoms and } 7 \text { with nondiagnostic ECGs }\end{array}$ & 109 & 142 \\
\hline $\begin{array}{l}\text { Excluding } 25 \text { patients with } \\
\text { contraindications to fibrinolytic therapy }\end{array}$ & 109 & 139 \\
\hline $\begin{array}{l}\text { Excluding } 84 \text { patients who required } \\
\text { cardiopulmonary resuscitation, } \\
\text { intubation or defibrillation before or } \\
\text { during primary PCl }\end{array}$ & 102 & 137 \\
\hline $\begin{array}{l}\text { Excluding all patients in the previous } 3 \\
\text { rows }\end{array}$ & 102 & 138 \\
\hline
\end{tabular}

Note: $\mathrm{ECG}=$ electrocardiogram, $\mathrm{PCI}=$ percutaneous coronary intervention. 